\title{
The Dasypodidae (Mammalia, Xenarthra) from the Urso Fóssil Cave (Quaternary), Parque Nacional de Ubajara, State of Ceará, Brazil: paleoecological and taxonomic aspects
}

\author{
PAULO V. OLIVEIRA ${ }^{1 *}, 5$, ANA MARIA RIBEIRO ${ }^{2}$, ÉDISON V. OLIVEIRA ${ }^{3}$ and MARIA SOMÁLIA S. VIANA ${ }^{4}$ \\ ${ }^{1}$ Programa de Pós-Graduação em Geociências, Universidade Federal de Pernambuco, \\ Av. Acadêmico Hélio Ramos, s/nº, Cidade Universitária, 50740-530 Recife, PE, Brasil \\ ${ }^{2}$ Museu de Ciências Naturais, Fundação Zoobotânica do Rio Grande do Sul, \\ Av. Dr. Salvador França, 1427, Jardim Botânico, 90690-000 Porto Alegre, RS, Brasil \\ ${ }^{3}$ Laboratório de Paleontologia, Departamento de Geologia, Universidade Federal de Pernambuco, \\ Av. Acadêmico Hélio Ramos, s/nº, Cidade Universitária, 50740-530 Recife, PE, Brasil \\ ${ }^{4}$ Laboratório de Paleontologia, Museu Dom José, Universidade Estadual Vale do Acaraú, \\ Av. Dom José, 878, 62010-290, Sobral, CE, Brasil \\ ${ }^{5}$ Universidade Federal do Piauí, Campus Sen. Helvídio Nunes de Barros, \\ Rua Cícero Duarte, s/nº, Junco, 64600-000 Picos, PI, Brasil \\ Manuscript received on December 20, 2012; accepted for publication on June 12, 2013
}

\begin{abstract}
This paper deals with xenarthrans osteoderms assigned to Dasypus aff. D. novemcinctus, Euphractus sexcinctus and Cabassous sp. The material was collected in subsurface, from 0.10 to $0.60 \mathrm{~m}$ in the Urso Fóssil Cave, Parque Nacional de Ubajara, State of Ceará, northeastern Brazil. The ages of sediment samples from levels 4 and 5 (depths of 0.40 and $0.50 \mathrm{~m}$ ) were determined by thermoluminescence technique, and indicated ages of 8,000 and 8,200 years BP for each layer respectively. The presence in these layers of early Holocene xenarthrans taxa can contribute to the understanding of the biotic evolution of the northwest region of Ceará during the last 10,000 years. Two of the three identified taxa still occur in the region: Dasypus novemcinctus and Euphractus sexcinctus. The Dasypodidae fauna here reported includes animals with generalist feeding habits and current wide geographical distribution. It is suggested, therefore, that the climatic and environmental conditions in the early Holocene were very similar the actual ones, and that the absence of Cabassous may be conditioned to other factors, such as anthropogenic action and loss of habitat by fragmentation of the vegetation.
\end{abstract}

Key words: Mammals, Dasypodidae, Holocene, cave, Parque Nacional de Ubajara, northeastern Brazil.

\section{INTRODUCTION}

The group of Xenarthras is known in South America since paleocene times. The order Cingulata stands out due to its diversity and rich fossil record, which indicates that xenarthran's arrival in Central and North America took place between the Late

Correspondence to: Paulo Victor de Oliveira E-mail: victoroliveira.paleonto@gmail.com * $\mathrm{CNPq}$
Miocene and Pliocene, during the Great American Biotic Interchange (GABI; Webb and Marshall 1982, Eisenberg and Redford 1999). According to McKenna and Bell (1997), the Cingulata includes the families Protobradidae Ameghino, 1902; Dasypodidae Gray, 1821; Peltephilidae Ameghino, 1894; Pampatheriidae Paula Couto, 1954; Palaeopeltidae Ameghino, 1895; and Glyptodontidae Gray, 1869, although the validity of some of 
these families is questioned by some authors (e.g. Gaudin and Wible 2006). The Quaternary record of the Dasypodidae comes from South American Pleistocene and Holocene of Argentina, Bolivia, Brazil, Ecuador, Paraguay, Uruguay and Venezuela (Oliveira and Pereira 2009).

The armadillos are distributed from Oklahoma in the United States to south of the Strait of Magellan in Chile and were recently introduced into Florida (Eisenberg and Redford 1999). According to Wilson and Reeder (2005), the Dasypodidae includes 21 extant species distributed in nine genera that belong to three subfamilies: Dasypodinae, genus Dasypus Linnaeus, 1758; Euphractinae, genera Calyptophractus Fitzinger, 1871, Chaetophractus Fitzinger, 1871, Chlamyphorus Harlan, 1825, Euphractus Wagler, 1830 and Zaedyus Ameghino, 1889; and Tolypeutinae, genera Cabassous McMurtrie, 1831, Priodontes F. Cuvier, 1825 and Tolypeutes Illiger, 1811.

In the Quaternary of Brazil, the Dasypodidae is represented by the genera: Propraopus Ameghino, 1881, Tolypeutes, Dasypus, Cabassous and Euphractus (Oliveira and Pereira 2009). Propraopus is an extinct taxon which occurs from the Pleistocene to the Holocene of Argentina, Brazil, Ecuador, Uruguay, Venezuela, and possibly of Bolivia and Paraguay; Tolypeutes is recorded for the Lujanian deposits (late Pleistocene) of Argentina (Paula Couto 1979); Dasypus occurs in the Pleistocene and Holocene of Argentina, Brazil, Uruguay and Venezuela (Oliveira and Pereira 2009); Cabassous is reported for the Pleistocene of Brazil (States of Minas Gerais and São Paulo; Paula Couto 1979); and Euphractus occurs in the Pampean of Argentina (Pleistocene) and it was possibly present in the Brazilian Pleistocene (Paula Couto 1979).

In Brazil, Dasypus, Cabassous and Euphractus are reported for the States of Acre, Bahia, Mato Grosso do Sul, Minas Gerais, Piaú, Rio Grande do Sul, and São Paulo in deposits of the late Pleistocene and early Holocene (Ameghino 1907, Paula Couto 1973, 1979, 1983, Guérin et al. 1996, Cartelle 1999, Faure et al. 1999, Ranzi 2000, Salles et al. 2006, Oliveira and Pereira 2009, Castro et al. 2013).

The material of Dasypodidae comprises several bone remains collected in the "Sala da Entrada" of the Urso Fóssil Cave, Parque Nacional de Ubajara (PNU), located in the northwest part of State of Ceará, Brazil. In the current faunal list, only Dasypus novemcinctus and Euphractus sexcinctus are recorded. The region integrating the karst system of the PNU lacks paleomastozoological studies, especially those involving smaller forms, such as armadillos. It is known that some small-sized and medium-sized species are highly specialized, and can provide important data regarding the occurrence of pronounced environmental changes during the Quaternary. Furthermore, taxonomic studies with species of these sizes are still rare in Brazil.

The main purposes of this paper are to present new records of Dasypodidae for the Quaternary mammal fauna of the Ubajara region and to provide information related to their geographical distribution and paleoecology.

GEOGRAPHIC AND STRATIGRAPHIC LOCATION

The Parque Nacional de Ubajara (PNU) is situated within the municipality of Ubajara, in the Ibiapaba cuesta, in the northwest of the State of Ceará (Figure 1). This is an area of a moist forest enclave on a plateau inserted in the Caatinga Biome, whose average elevation is around $900 \mathrm{~m}$ (Oliveira et al. 2011b). The Ibiapaba cuesta range runs north and south, comprising the boundary between States of Ceará and Piauí. Ibiapaba highland corresponds to the east edge of the Parnaíba Basin, which has a discordant contact with its east slope where Neoproterozoic Frecheirinha Formation (Ubajara Group, Ubajara Basin) crops out (Nascimento et al. 1981, Oliveira 2010). These outcroppings in the Ubajara region are characterized as limestone 
formations of exokarst. They comprise nine hills over $40 \mathrm{~m}$ of height (Nascimento-Junior and Paiva-Neto 2005) where 14 underground cavities with favorable conditions to the accumulation of modern and fossil organic remains, can be found (IBAMA 2002, Oliveira 2010).
Among these cavities, the Urso Fóssil Cave $03^{\circ} 49^{\prime} 58^{\prime \prime} \mathrm{S} / 40^{\circ} 53^{\prime} 34.4^{\prime \prime} \mathrm{W}$ in the Pendurado hill, stands out due to its high potential for paleontological studies, evidenced by the considerable accumulation of bone and dental specimens (Oliveira 2010, Oliveira et al. 2011a).

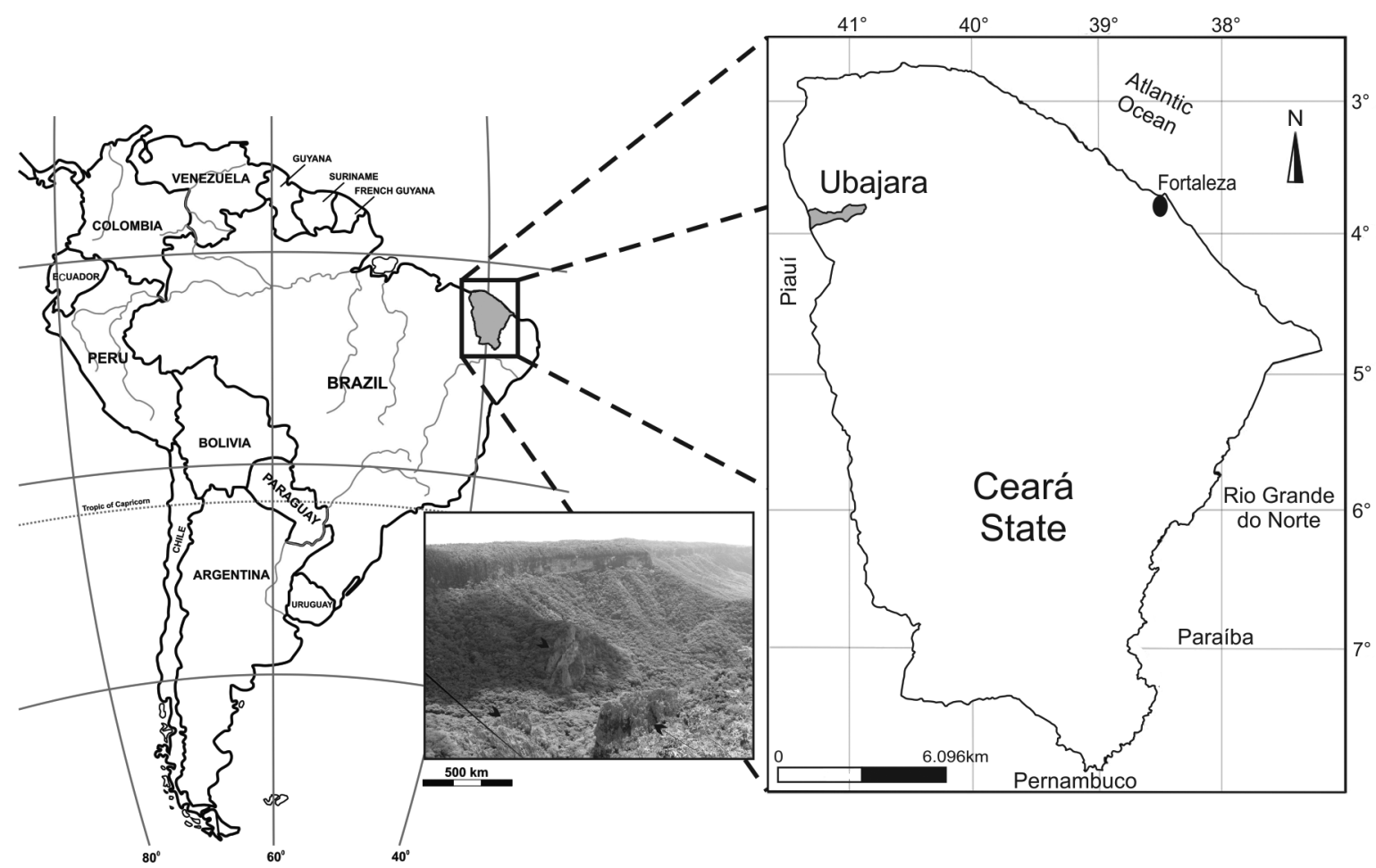

Figure 1 - Location map of the National Park of Ubajara, State of Ceará (above) and the limestone outcroppings (below) indicated by arrows. Modified from Oliveira et al. (2011b).

The caves of the Ubajara region are less expressive in size $(40-1,120 \mathrm{~m})$ when compared to other Brazilian caves (e.g. Toca da Boa Vista and Toca da Barriguda which are 107,000 m and $33,000 \mathrm{~m}$ long, respectively). This fact contributes to the accumulation of skeletal remains of a small and medium-sized fauna, mainly mammals. Until now there is only one reference related to the presence of Pleistocene megafauna in the region (Trajano and Ferrarezzi 1994). It is represented by a skull and mandible of Arctotherium brasiliense (= A. wingei Ameghino 1902, see Soibelzon 2004 for a systematic review of the Tremarctinae fossils in South America).
Teeth and vertebrae of reptiles were also found and reported by Hsiou et al. (2012).

The material presented here was collected in the first room of the Urso Fóssil Cave, known as "Sala da Entrada", which also includes numerous bone fragments which are still undetermined (highly fragmented), isolated teeth, seeds and gastropods already reported by Oliveira et al. (2011b). The material was collected in layers from 0.10 to $0.60 \mathrm{~m}$, as shown in Figure 2. The ages of the layers 4 and $5(0.40$ and $0.50 \mathrm{~m})$ were determined by thermoluminescence (TL), resulting in 8,000 \pm 990 years BP and 8,200 \pm 980 years BP (early Holocene), for each layer respectively. 


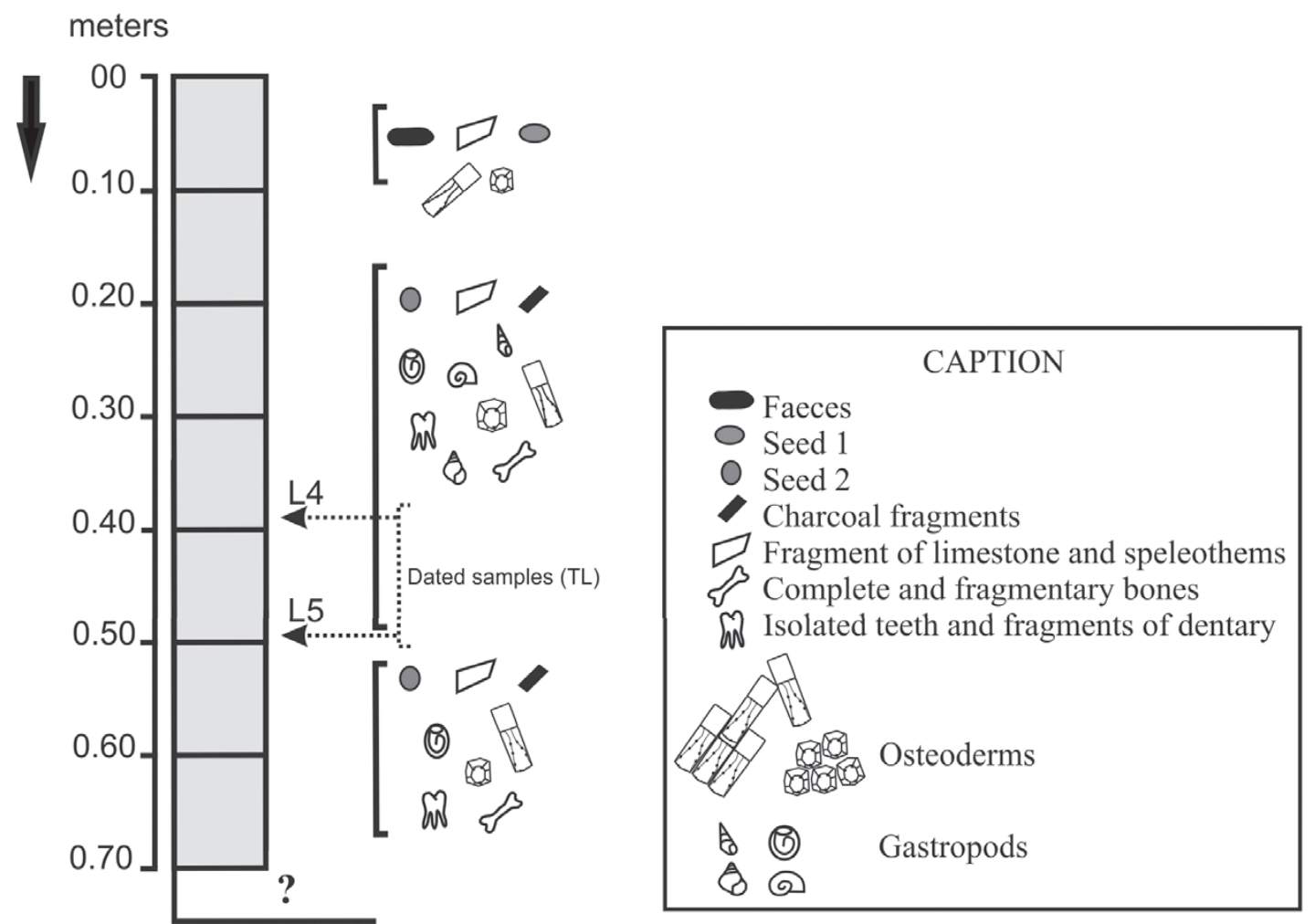

Figure 2 - Stratigraphic section of "Sala da Entrada" Urso Fóssil Cave, showing the L4 and L5 levels from where dated samples were obtained. Urso Fóssil Cave. Modified from Oliveira et al. (2011b).

\section{MATERIALS AND METHODS}

The specimens are complete and fragmentary osteoderms of Dasypodidae housed at the scientific Paleomastozoology Collection of the Museu Dom José (MDJ M), Municipality of Sobral, CE, Brazil, under the MDJ acronym. The material was compared with modern Dasypodidae, such as Dasypus novemcinctus, Euphractus sexcinctus and Cabassous tatouay from the Mammal Collections of the Museu de Ciências Naturais, Fundação Zoobotânica do Rio Grande do Sul (MCN/FZBRS) Porto Alegre, RS, Brazil and from the Universidade Federal de Pernambuco (UFPE), Recife, PE, Brazil. The nomenclature (Figure 3 ) and systematics used for osteoderms follow Wilson and Reeder (2005) and Oliveira and Pereira (2009), as well as Paula Couto (1979) and Hill (2006). Measurements were made in millimeters using digital calipers accurate to $001 \mathrm{~mm} / 0.0005$ ".

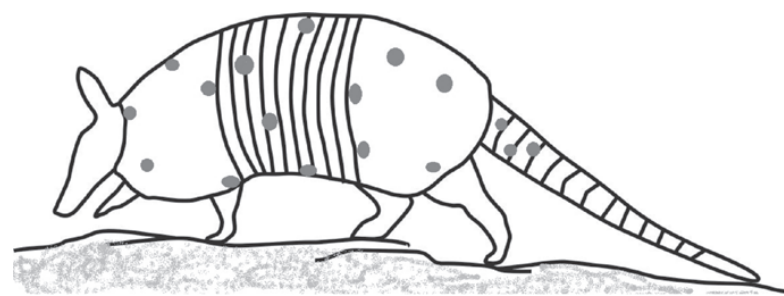

$\mathbf{A}$

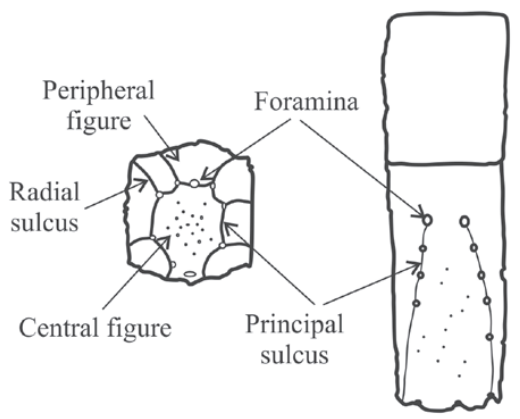

Figure 3 - A. Schematic drawing showing the position of the armadillo osteoderms; B. Terminology used for osteoderm morphology (dorsal view) in Dasypus. Fixed osteoderm (left) and moveable osteoderm (right). Modified from Oliveira and Pereira (2009). 


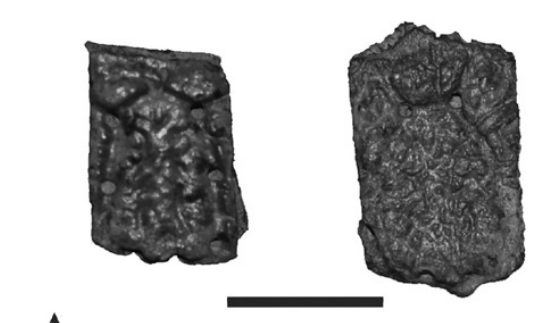

A

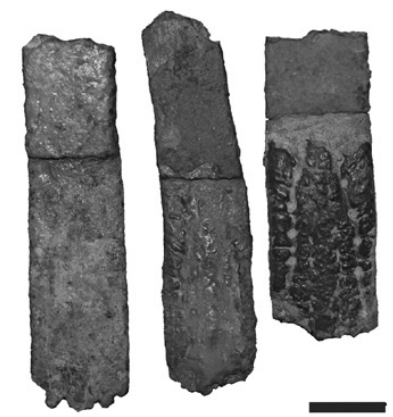

D

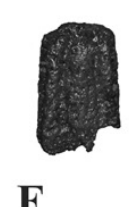

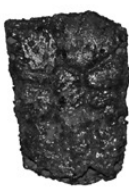
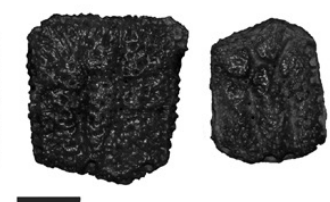

B
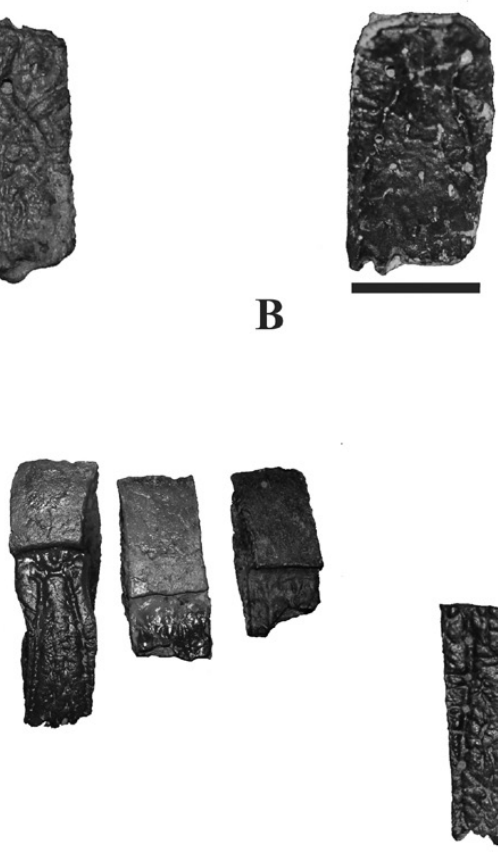

G
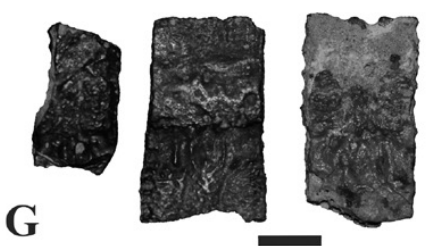

E
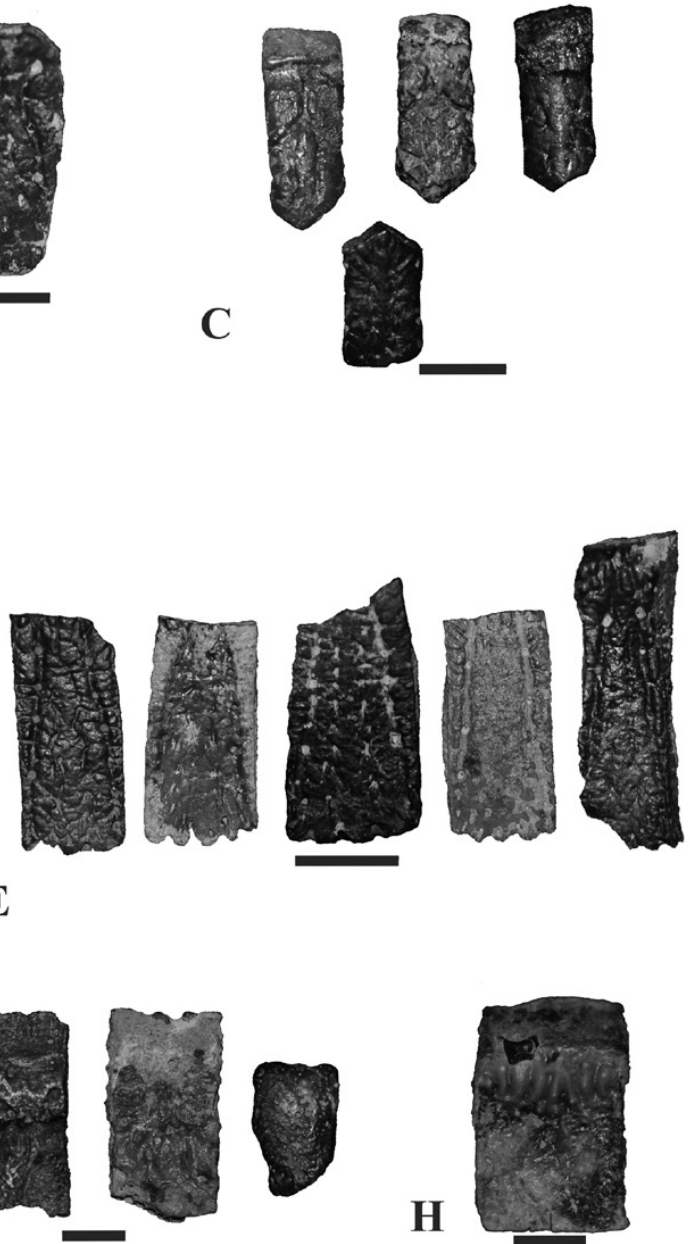

Figure 4 - Dasypus aff. D. novemcinctus. A. MDJ M-831 and 873, fixed osteoderms; B. MDJ M-834, semi-moveable osteoderm; C. MDJ M-869, 862, 882 (at top) and 859 (at bottom), caudal osteoderms; D-E. MDJ M-804, 826, 825, 827, 809, 851, 833, 817, 836, 829 and 830, left to right, fragmentary moveable osteoderms. Euphractus sexcinctus. F. MDJ M-803, 801, 821 and 822, left to right, fixed osteoderms; G. MDJ M-852, 824, 823 and 872, left to right, fragmentary moveable osteoderms. Cabassous sp. H. MDJ M-840, moveable osteoderm. All osteoderms are in dorsal view. Scale bars $=0.5 \mathrm{~cm}$.

The sediment samples were collected in PVC pipe, processed and used for absolute dating by Thermoluminescence (TL) technique made in the Laboratório de Vidros e Datação da Faculdade de Tecnologia de São Paulo, and thus identified LVD 2401 and LVD 2402 ( 0.40 and $0.50 \mathrm{~m}$, respectively).

Comparative material: Dasypus novemcinctus (MCN-2440, 2553, 2571， 2782， 2783， 2836; UFPE-1706, 1229, 2429, 2432, 2435-2440, 2446); Euphractus sexcinctus (MCN-919, 2757; UFPE-1950, 2384, 2431, 2433, 2434, 2444, 2450); Cabassous tatouay (MCN-2556; UFPE-462, 839, 1288).

\section{RESULTS}

SYSTEMATICS

Superorder Xenarthra Cope, 1889

Order Cingulata Illiger, 1811

Superfamily Dasypodoidea Gray, 1821

Family Dasypodidae Gray, 1821

Subfamily Dasypodinae Gray, 1821

Tribe Dasypodini Gray, 1821

Genus Dasypus Linnaeus, 1758

Dasypus aff. D. novemcinctus (Linnaeus, 1758)

(Figure 4A-E; Table I) 
Material. MDJ M-831, 873, 902-905, 948, 950969, 1045-1053, 1058, 1059, 1086-1097, fixed osteoderms (scapular and pelvic portion); MDJ M-834, 949, 1044, semi-moveable osteoderms; MDJ M-804-807, 809-819, 825-830, 832, 833, 835$839,850,851,853-855,857,858,860,863,865$, $868,870,871,874,912-936,970-1043,1060-1065$, 1071-1085, 1098-1111, moveable osteoderms; MDJ M-802, 859, 862, 869, 906-911, 937-947, 1054-1057, 1066-1070, caudal osteoderms.

Description. The fixed osteoderms belong to the scapular and the pelvic portion of the carapace, including osteoderms from the edges, anterior (MDJ M-1059) and lateral regions, and from the median portion of the dorsal region (see measures in Table I). The morphology of the fixed osteoderms is variable, quadrangular, pentagonal or hexagonal. Almost all of them are dorsally ornamented by well marked sulci and foramina, and in some cases, protuberances occuring in the most anterior region. The ventral surface is flat or slightly concave, but is always smooth with neurovascular foramina. The dorsal surface of the specimen MDJ M-831 is ornamented by two peripheral figures in the anterior region, which are separated from the posterior region by two sinuous sulci. In the median area of each sulcus there is a foramen from where two other sulci originate in anteroposterior direction reaching the distal edge of osteoderms thus limiting the central figure. The central figure is distally convex. Under these sulci, there are two pairs of foramina; between these two sulci is the central figure, with an irregular surface marked by some punctuations, which are randomly arranged. The specimen MDJ M-873 is pentagonal in shape and its ventral surface is smooth and flat. Most of the dorsal surface is occupied by a central figure, separated from three peripheral figures. The latter are smaller than the central figure and limited by well marked sulci bearing two proximal and four distal foramina. One of the peripheral figures is situated on the most anterior portion of the dorsal surface whereas the other two are arranged anterolaterally. The specimens MDJ M-951, 952, 955-958 are from the lateral edge of the carapace. Ornamentations are not common in these specimens, but when they are present they are very simple ones. In the middle area of the distal portion, foramina of hair follicles can be found in some of the fixed osteoderms.

The semi-moveable osteoderms (specimens MDJ M-834, 949 and 1044) are from a transitional area and therefore share ornamentation patterns with both fixed and moveable osteoderms. The semi-moveable osteoderms may exhibit two sulci. Under the sulci there are some unpaired foramina, as well as some punctuations. The latter are also present in the central area between the two sulci.

The moveable osteoderms include complete specimens and fragments of several sizes. The complete movable osteoderms are elongated and have two portions (see Figure 4D-E, Table I). The anterior portion corresponds to the articulation area and it is smooth and table-like shaped, i.e., it is higher and thicker than the posterior portion. The surface of the table-like area is irregular due to the presence of dorsal ornamentations, such as foramina and sulci. The transition between the anterior and posterior portions is marked by a difference in thickness, but also by the presence of roughness. Still on the dorsal surface, on the anterior limit of the posterior portion, it is observed that two sulci originate very close to each other, but then diverge posteriorly. In some specimens these sulci seem to limit an elongated and subtriangular figure, similar to an isosceles triangle, with the basis towards the distal edge of the osteoderm. In this region of the osteoderm usually there are four foramina, possibly from hair follicles. Smaller foramina occur in the two aforementioned sulci and they can vary in number, arranged anteroposteriorly, paired or unpaired. Also, in the area between these sulci there are punctuations, smaller than the foramina. The lateral articular surfaces show strongly serrated edges in general. The ventral surface 
of the osteoderm may be flat or slightly concave, lacking ornamentation. The peripheral figures also show some punctuations. The specimen MDJ M-860 corresponds to the last osteoderm (right edge) of the sequence of moveable bands. The osteoderms MDJ M-862, 869, 906-909, 937, 945, 1054-1056, 1067 and 1068 , belong to the first row of one of the tail rings. The anterior portion is table-like and much reduced, whereas the posterior portion is larger and exhibits the following ornamentations: one medial sulcus which branches to both sides in two sulci, in which there are two pairs of foramina. The last pair reaches the lateral edge, where two pairs of foramina are also present.
Thus, forming one pentagonal figure with an irregular surface. The distal end is V-shaped and it is articulated to the anterior end of the osteoderms from the second row of the caudal ring. The specimens MDJ M-859, 910, 911, 946 and 947 belong to the second row of the tail ring, which presents five edges and bears a V-shaped proximal end. The MDJ M-802 belongs to a ring of the distal portion of the tail and like the others, it has two portions (proximal and distal), lacking ornamentation. The ventral surface of the specimen is concave and bears some lines arranged longitudinally. However, the most distal portion of the surface is smooth, such as is observed in MDJ M-1057.

TABLE I

Measurements (mm) of preserved osteoderms assigned to Dasypus aff. D. novemcinctus. Abreviations: TL, total length; PW, proximal width; DW, distal width; PT, proximal thickness; DT, distal thickness. When $\mathbf{n}>1$, first line is mean \pm standard deviation, second line is observed range, and third line is number of specimens measured (n).

\begin{tabular}{cccccc}
\hline Osteoderm & TL & PW & DW & PT & DT \\
\hline \multirow{2}{*}{ Fixed } & $6.15 \pm 1.44$ & $4.73 \pm 0.91$ & $4.89 \pm 0.93$ & $1.87 \pm 0.53$ & $1.85 \pm 0.55$ \\
& $3.31-9.17$ & $2.61-6.61$ & $2.61-6.61$ & $0.1-2.78$ & $0.1-2.78$ \\
& $(38)$ & $(40)$ & $(40)$ & $(40)$ & $(38)$ \\
Semi-moveable & 11.31 & 4.22 & $5.09 \pm 0.84$ & $1.15 \pm 0.05$ & $1.34 \pm 0.37$ \\
& & & $4.5-5.69$ & $1.12-1.19$ & $0.99-1.74$ \\
Moveable & $11.24 \pm 5.93$ & $5.20 \pm 0.96$ & $5.11 \pm 0.78$ & $1.74 \pm 0.38$ & $1.42 \pm 0.29$ \\
& $4.66-25.84$ & $3.54-8.07$ & $3.06-7.4$ & $0.80-2.80$ & $0.81-3.03$ \\
& $(22)$ & $(111)$ & $(162)$ & $(114)$ & $(172)$ \\
Caudal & $10.78 \pm 1.51$ & $4.22 \pm 0.78$ & $4.28 \pm 0.58$ & $1.59 \pm 0.43$ & $1.95 \pm 0.41$ \\
& $7.22-13.07$ & $3.19-6.52$ & $3.26-5.76$ & $0.77-2.6$ & $1.32-2.66$ \\
& $(29)$ & $(29)$ & $(30)$ & $(29)$ & $(30)$ \\
\hline
\end{tabular}

Subfamily Euphractinae Winge, 1923

Tribe Euphractini Winge, 1923

Genus Euphractus Wagler, 1830

Euphractus sexcinctus (Linnaeus, 1758)

(Figure 4F-G; Table II)

Material. MDJ M-801, 803, 821, 822, 900, 901, 1117, fixed osteoderms; MDJ M-1116, 1120, semimoveable osteoderms; MDJ M-823, 824, 852, $872,899,1118,1119$, moveable osteoderms; MDJ M-820, molariform tooth.

Description. The fixed osteoderms exhibit five articular surfaces (pentagonal shape), except for the specimens MDJ M-803, which is fragmentary, and MDJ M-901, which is rectangular. The measurements of the specimens are in Table II. The dorsal surface is marked by sulci originating on the proximal and lateral ends and which run towards the center, where they converge into an arched sulcus. At the distal end, there are foramina for hair follicles in variable number, as well as tiny foramina both inside and outside of the sulci. The ventral surface of these osteoderms is concave and relatively smooth. The specimen MDJ M-803 differs from the other fixed osteoderms due to the absence of foramina and the presence of a shallow sinuous sulcus, 
which is more elongated than in other specimens. These morphological differences are due to the fact that osteoderms come from different places in the carapace. MDJ M-803 has two foramina for hair follicles, only visible in the ventral surface, due to the fragmentation of its distal end.

The semi-moveable osteoderms MDJ M-1116 and 1120 belong to an intermediate zone, between the scapular portion of the carapace and the first row of moveable osteoderms. The material bears a well-marked sulcus with an inverted U-shape. From this sulcus four or five sulci reach the anterior end of the osteoderm, bordering three to four peripheral figures. The foramina for hair follicles are restricted to the end of the posterior portion and vary in number (three or four).

The moveable osteoderms are represented only by fragments. The specimens MDJ M-823 and 824 are similar in morphology. Both display a very marked division of the dorsal surface into anterior and posterior regions. The anterior region apparently lacks ornamentation, whereas the posterior one is well ornamented by two sulci that originate in this medial region. Due to their poor preservation, it is not possible to observe the presence of foramina in MDJ M-823 and 824, unlike MDJ M-1119, which has its posterior portion preserved, and two sulci that contain three foramina each, as well as two other foramina for hair follicles at the distal end, can be seen. The lateral articular surfaces of the specimens present a rough area, unlike the ventral surface which is smooth, convex laterally and medially concave. The specimen MDJ M-872 belongs to the lateral edge of the carapace and differs from other moveable osteoderms by the lack of ornamentation and by its irregular shape. The dorsal surface of the specimen is convex and the ventral one is concave. Both surfaces have a smooth aspect. The specimen MDJ M-820 corresponds to a molariform tooth, which is semicircular in occlusal view and cylindrical in lingual and labial views. The tooth presents two crests located on the most anterior region; one crest is vestibular and the other lingual.

TABLE II

Measurements (mm) of preserved osteoderms assigned to Euphractus sexcinctus. Abbreviations: TL, total length; PW, proximal width; DW, distal width; PT, proximal thickness; DT, distal thickness. When $\mathbf{n}>1$, first line is mean \pm standard deviation, second line is observed range, and third line is number of specimens measured (n).

\begin{tabular}{cccccc}
\hline Osteoderm & TL & PW & DW & PT & DT \\
\hline \multirow{2}{*}{ Fixed } & $13.57 \pm 1.19$ & $9.37 \pm 2.06$ & $9.78 \pm 1.17$ & $2.67 \pm 0.58$ & $2.38 \pm 0.72$ \\
& $11.56-14.47$ & $6.28-12.64$ & $8.57-11.5$ & $1.72-3.35$ & $1.26-3.41$ \\
& $(5)$ & $(6)$ & $(5)$ & $(6)$ & $(7)$ \\
Semi-moveable & $14.26 \pm 1.93$ & $9.06 \pm 0.29$ & $8.78 \pm 0.07$ & $3.04 \pm 0.10$ & $2.35 \pm 0.70$ \\
& $12.9-15.63$ & $8.86-9.27$ & $8.73-8.83$ & $2.97-3.12$ & $1.86-2.85$ \\
& $(2)$ & $(2)$ & $(2)$ & $(2)$ & $(2)$ \\
Moveable & & $7.26 \pm 2.09$ & $6.82 \pm 2.16$ & $2.07 \pm 0.65$ & $2.35 \pm 0.57$ \\
& 10.91 & $4.45-9.36$ & $4.92-9.19$ & $1.46-2.85$ & $1.75-3.15$ \\
& & $(4)$ & $(5)$ & $(5)$ & $(5)$ \\
\hline
\end{tabular}

Subfamily Tolypeutinae Gray, 1865

Tribe Priodontini Gray, 1873

Genus Cabassous McMurtrie, 1831

\section{Cabassous sp.}

(Figure 4H; Table III)

Material. MDJ M-1113, fixed osteoderm; MDJ M-840, 1112, 1114, 1115, moveable osteoderms.
Description. The MDJ M-1113 is slightly hexagonal, but its surface is of a different size, contributing to an anteroposteriorly elongated aspect. The specimen possibly belongs to the second or third row of the scapular portion of the carapace and its dorsal surface is marked by small and shallow punctuations and a wellmarked sulcus in an inverted U-shape. Concerning the moveable osteoderms, they are rectangular in 
shape, their dorsal surface is ornamented and the ventral surface is smooth and slightly lowered at the center in longitudinal axis. The anterior portion is table-like, smooth and smaller than the posterior portion. Between the anterior and posterior portions, there is an ornamented area, although the posterior portion itself does not have ornamentation, but only some punctuations and foramina for hair follicles at the distal end. The measurements of the specimens are in Table III.

\section{TABLE III}

Measurements (mm) of preserved osteoderms assigned to Cabassous sp. Abreviations: TL, total length; PW, proximal width; DW, distal width; PT, proximal thickness; DT, distal thickness. When $\mathbf{n}>1$, first line is mean \pm standard deviation, second line is observed range, and third line is number of specimens measured (n).

\begin{tabular}{cccccc}
\hline Osteoderm & TL & PW & DW & PT & DT \\
\hline Fixed & 10.57 & 7.32 & 8.71 & 2.81 & 2.61 \\
& $13.27 \pm 4.55$ & $9.42 \pm 1.88$ & $9.84 \pm 0.90$ & $2.09 \pm 0.83$ & $1.13 \pm 0.89$ \\
Moveable & $10.06-16.49$ & $8.09-10.75$ & $9.2-10.48$ & $1.53-3.3$ & $1.13-2.89$ \\
& $(2)$ & $(2)$ & $(2)$ & $(4)$ & $(3)$ \\
\hline
\end{tabular}

\section{DISCUSSION AND CONCLUSIONS}

The analysis of the osteoderms from the Urso Fóssil Cave was carried out by comparison with extant Dasypodidae taxa of the region, as well as by comparison with those recorded for the late Pleistocene and Holocene of Brazil, and belonging to the following taxa:Dasypus, Cabassous, Euphractus, Tolypeutes and Propraopus. The specimens studied here are diverse in shape, size and ornamentation, reflecting the characteristics of different species, and the different positions they occupied in the carapace. Based on the morphological/ornamentation analysis and the comparison with extant specimens of Dasypus novemcinctus (MCN-2440, 2553, 2571, 2782, 2783, 2836; UFPE-1706, 1229, 2429, 2432, 2435-2440, 2446) we found that most of the material described in the present study showed considerable affinity to this species. The other osteoderms and the molariform tooth MDJ M-820, share morphological characteristics with Euphractus sexcinctus (MCN919, 2757; UFPE-1950, 2384, 2431, 2433, 2434, $2444,2450)$. Although this material is fragmentary we can also observe that osteoderms are from different regions of the carapace, comprising fixed bands, semi-moveable, moveable and caudal osteoderms. Finally, the specimens MDJ M-840, 1112, 1113, 1114 and 1115 showed morphological similarities to the osteoderms of Cabassous tatouay (MCN-2556; UFPE-462, 839, 1288). However, due to the small sampling and to the lack of extant specimens of Cabassous unicinctus for comparison, we assigned our material to Cabassous sp. We believe it is improbable that the specimens studied here could be attributed to $C$. centralis and / or to $C$. chacoensis, since these taxa do not comprise species that occur in Brazil.

Based on a literature review concerning the studies of the Caatinga and its fauna, which was published between the years 1887 and 2000, Oliveira et al. (2003) provided a list of mammal species that occur in the Caatinga. According to this list, Dasypus septemcinctus, D. novemcinctus, Cabassous sp., Euphractus sexcinctus and Tolypeutes tricinctus occur in the States of Alagoas, Bahia, Ceará, Minas Gerais, Paraíba, Pernambuco, Piauí, Rio Grande do Norte and Sergipe. Although they are taxa with broad current distribution in Brazil, their occurrence as fossils is rather scarce (see Figure 5).

Regarding the deficiency in data related to small and medium-sized fossil mammals, we believe this happens because most publications are concerned with the study of megafauna, and because of the lack of use of specific methods to collect remains of small animals. 

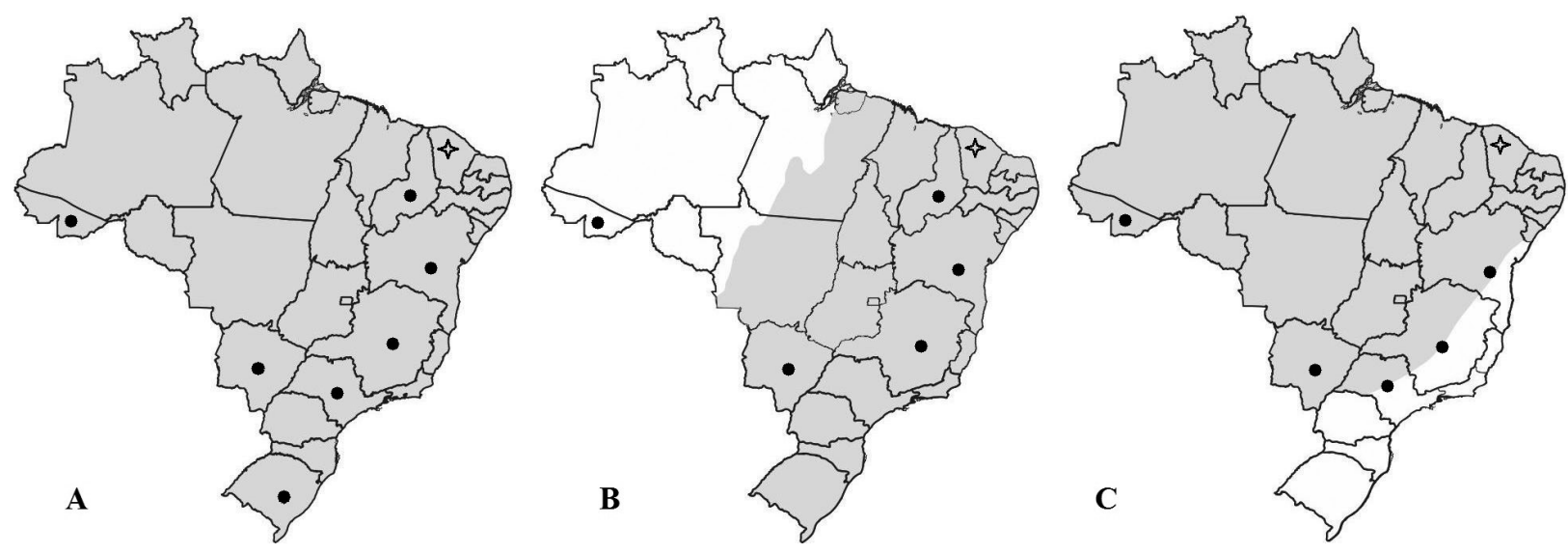

Figure 5 - Maps showing the current area of distribution of the species Dasypus novemcinctus (A), Euphractus sexcinctus (B) and Cabassous unicinctus (C) in Brazil (Modified from Eisenberg and Redford 1999). In evidence the fossil occurrences according to Ameghino (1907), Paula Couto (1973, 1979, 1983), Guérin et al. (1996), Faure et al. (1999), Salles et al. (2006), Oliveira and Pereira (2009) and Castro et al. (2013), and the presence of these genera in the State of Ceará as a contribution of this paper.

Currently, Dasypus is distributed from the south-central part of the United States to the Rio Negro Province in Argentina; Cabassous from the south of Mexico to the north of Argentina; and Euphractus is found in the savannas of Suriname, in Brazil next to the border with Suriname, southern Uruguay, eastern and western Paraguay, and south of the Province of Buenos Aires in Argentina (Eisenberg and Redford 1999). According to Meritt Jr (1985), Cabassous inhabits grasslands and highlands [e.g. plateaus and mountains], while Ranzi (2000) said that Cabassous and Dasypus are inhabitants of forest/savanna, and Euphractus is found in savanna areas. According to Redford (1985), Cabassous feeds on ants and termites, and other arthropods. Dasypus is a terrestrial insectivore which feeds on termites; and Euphractus displays a carnivorous-omnivorous feeding habit, a generalist consuming any animal matter, as well as various types of fruits and tubers.

The Dasypodidae fauna reported here differs from that currently found in the area only with regards to Cabassous. However, as noted above, the taxa reported in this study comprise mammals with generalist habits and wide geographical distribution (see Figure 5), thus preventing us from providing a more precise paleoenvironmental diagnosis. Considering the geographical distribution of the taxa recorded, it is suggested that the climatic and environmental conditions were very similar to the current ones. However, the absence of Cabassous may be subject to other factors such as antropic action and loss of habitat by fragmentation of the vegetation.

\section{ACKNOWLEDGMENTS}

The authors are grateful to G. Lessa (UFV), C.L. Ximenes and A.S.T. Santos (MUPHI), D. Lima (COOPTUR) and G.C. Oliveira (UFPE) for their support during fieldwork. They would also like to thank the employees of the PNU, F.H.S. Bezerra and N.M.P. Gomes; M. Jardim (MCN/FZBRS) and D. Astua (UFPE) for granting access to collections under their care; Museu Dom José (MDJ) for the loan of the specimens; M.C. Castro (UNLP) for helping with references and discussions; E.C. Holanda (UFRR) for helping with the analysis of measurements; K.O. Porpino (UERN) for carefully reading and providing suggestions to earlier versions of the manuscript; and the anonymous reviewers for their suggestions. This work received support from Conselho Nacional de Desenvolvimento Científico 
e Tecnológico (CNPq, Universal/473952/2008-4), Fundação Cearense de Apoio ao Desenvolvimento Científico e Tecnológico (FUNCAP, BPI-03411.07/08), Instituto de Apoio Desenvolvimento da UVA (IADE-UVA) and Coordenação de Aperfeiçoamento de Pessoal de Nível Superior (CAPES) and CNPq (142942/2010-3) for Master and Doctoral Fellowships respectively.

\section{RESUMO}

Este artigo refere-se a osteodermos de xenarthras atribuídos a Dasypus aff. D. novemcinctus, Euphractus sexcinctus e Cabassous sp. O material foi coletado em subsuperfície, de 0,10 a $0,60 \mathrm{~m}$ na Gruta do Urso Fóssil, Parque Nacional de Ubajara, no estado do Ceará, nordeste do Brasil. As idades das amostras de sedimento dos níveis 4 e 5 (profundidades de 0,40 e $0,50 \mathrm{~m}$ ) foram determinadas pela técnica de termoluminescência, e indicaram idades de $8.000 \mathrm{e}$ 8.200 anos AP, respectivamente. A presença de táxons de xenarthras nestes níveis do Holoceno inicial, pode contribuir para um melhor entendimento da evolução biótica da região noroeste do Ceará durante os últimos 10.000 anos. Dois dos três táxons identificados ainda ocorrem na região: Dasypus novemcinctus e Euphractus sexcinctus. A fauna de Dasypodidae aqui relatada compreende animais de hábitos alimentares generalistas e com ampla distribuição geográfica atual. Sugere-se, pois, que as condições climáticas e ambientais no início do Holoceno foram muito semelhantes às atuais, e que a ausência de Cabassous pode estar condicionada a outros fatores, como ação antrópica e perda do habitat por fragmentação vegetacional.

Palavras-chave: Mamíferos, Dasypodidae, Holoceno, gruta, Parque Nacional de Ubajara, nordeste do Brasil.

\section{REFERENCES}

AMEGHINO CF. 1907. Notas sobre una pequeña colección de huesos de mamíferos procedentes de lãs grutas calcáreas de Iporanga en el estado de São Paulo, Brazil. In: TORCELLI AJ (Ed), 1916, Obras completas y correspondencia científica: Taller de Impressiones Oficiales 7: 102-153.
CARTElle C. 1999. Pleistocene Mammals of the Cerrado and Caatinga of Brazil. In: EISENBERG JF AND REDFORD KH (Eds), Mammals of the Neotropics, The Central Neotropics: The University of Chicago Press 3: 27-46.

Castro MC, Ribeiro AM, Ferigolo F And Langer MC. 2013. Redescription of Dasypus punctatus Lund, 1840 and considerations on the genus Propraopus Ameghino, 1881 (Xenarthra, Cingulata). J Vertebr Paleontol 33(2): 434-447.

EISENBERG JF AND REDFORD KH. 1999. Mammals of the Neotropics - The Central Neotropics: Ecuador, Peru, Bolivia, Brazil: The University of Chicago Press 3: 609.

FAURE M, GuÉRIN C AND PARENTI F. 1999. Découverte d'une mégafaune Holocène à la Toca do Serrote do Artur (Aire Archéologique de São Raimundo Nonato, Piauí, Brésil): Comptes Rendus de l'Academie des Science Paris, Paris, 329: 443-448.

GAUDIN TJ AND WIBLE JR. 2006. The phylogeny of living and extinct armadillos (Mammalia, Xenarthra, Cingulata): a craniodental analysis. In: Carrano MT, Gaudin TJ, Blob RW and Wible JR (Eds), Amniote Paleobiology: Perspectives on the Evolution of Mammals, Birds, and Reptiles: University of Chicago Press, Chicago, IL, p. 153-198.

GuÉrin C, Curvello MA, Faure M, Hugueney M AND Mourer-Chauviré C. 1996. A fauna Pleistocênica do Piauí (Nordeste do Brasil): relações paleoecológicas e biocronológicas: Fumdhamentos, São Raimundo Nonato 1: $55-103$.

HILL RV. 2006. Comparative anatomy and histology of xenarthran osteoderms: J Morphology 267: 1441-1460. doi: $10.1002 /$ jmor

HSIOU AS, OLIVEIRA PV, Ximenes CL AND VianA MSS. 2012. Lizards and snakes (Lepidosauria, Squamata) from the late Quaternary of the State of Ceará in northeastern Brazil. J Cave Karst Stud 74(3): 262-270. doi: 10.4311/2011PA0239

IBAMA - InstituTo BRAsileiro Do MeIO AMBIENTE E DOS RECURSOS RENOVÁVEIS. 2002. Parque Nacional de Ubajara: Plano de Manejo. Brasília: Ministério do Meio Ambiente. CD-ROM.

MCKenNA MC AND BELL SK. 1997. Classification of Mammals Above the Species Level: New York, Columbia University Press, $631 \mathrm{p}$.

MERITT JR DA. 1985. Naked-tailed armadillos, Cabassous sp. In: MONTEGOMERY GG (Ed), The evolution and ecology of armadillos, sloths, and vermilinguas: Smithsonian Institution Press, Washington and London, p. 389-391.

Nascimento DA, Gava A, Pires J and TteiXeira W. 1981. Geologia da folha SA. 24 - Fortaleza. In: Projeto Radambrasil. Rio de Janeiro: DNPM 21: 23-212.

NASCIMENTO-JUNIOR JV AND PAIVA-NeTO AO. 2005. Caracterização geológica e estrutural do metacalcário Frecheirinha na região do Parque Nacional de Ubajara e suas influências na espeleogênese: Curso de Graduação em Geologia, Universidade Federal de Fortaleza, Relatório de Graduação, 89 p. 
OLIVEIRA EV AND PEREIRA JC. 2009. Intertropical cingulates (Mammalia, Xenarthra) from the Quaternary of southern Brazil: systematics and paleobiogeographical aspects: Rev Bras Paleont 12(3): 167-178. doi:10.4072/rbp.2009.3.01

OLIVEIRA JA, GONÇALVES PR AND BONVICINO CR. 2003. Mamíferos da Caatinga. In: LEAL IR, TABARELLI $\mathrm{M}$ and SILVA JMC (Eds), Ecologia e conservação da caatinga: Ed. Universitária, Universidade Federal de Pernambuco, Recife, p. 275-333.

OliveIRA PV. 2010. Mamíferos do Neopleistoceno - Holoceno do Parque Nacional de Ubajara, Ceará: Programa de Pós-Graduação em Geociências, Universidade Federal do Rio Grande do Sul, Dissertação de Mestrado, 166 p. (Unpublished).

Oliveira PV, Lessa G, Viana MSS, Ximenes CL, Ribeiro AM, Oliveira EV, SANTOS AST, Hsiou AS, Holanda EC AND KERBER L. 2011a. Gruta do Urso Fóssil (Nordeste do Brasil) e sua fauna quaternária: dados preliminares. In: Livro de Resumos do XXII Congresso Brasileiro de Paleontologia, Natal, p. 651-653.

OLIVEIRA PV, VIANA MSS AND SIMONE LRL. $2011 \mathrm{~b}$. Eoholocene malacofauna (Gastropoda, Pulmonata) from a cave of National Park of Ubajara, Ceará State, Brazil: Estudos Geológicos 21(1): 85-93.

Paula Couto C DE. 1973. Edentados fósseis de São Paulo: An Acad Bras Cienc 45: 261-275.

Paula Couto C DE. 1979. Tratado de Paleomastozoologia: Rio de Janeiro, Acad Bras Cienc, 590 p.

PAula Couto C DE. 1983. Fossil Mammals from the Cenozoic of Acre, Brazil. VI - Edentata Cingulata: Iheringia. Sér Geol 8: 33-34.
RANZI A. 2000. Paleoecologia da Amazônia: megafauna do Pleistoceno. Florianópolis, Ed. da UFSC, 101 p.

REDFORD KH. 1985. Food habits of armadillos (Xenarthra: Dasypodidae). In: MONTEGOMERY GG (Ed), The evolution and ecology of armadillos, sloths, and vermilinguas: Smithsonian Institution Press, Washington and London, p. 429-437.

Salles L de O, Cartelle C, Guedes PG, Boggiani PC, JANOO A AND RUSSO CAM. 2006. Quaternary mammals from Serra da Bodoquena, Mato Grosso do Sul, Brazil: Boletim do Museu Nacional, Rio de Janeiro, Sér Zool 521: 1-12.

SoIBELZON LH. 2004. Revisión sistemática de lós Tremarctinae (Carnivora, Ursidae) fósiles de América del Sur. Rev Mus Argent Cienc Nat 6(1): 107-133.

Trajano E AND FERRAREzZI H. 1994. A fossil bear from northeastern Brazil, with a phylogenetic analysis of the South American extinct Tremarctinae (Ursidae): J Vert Paleont 14(4): 552-561.

WEBB SD AND MARSHALL LG. 1982. Historical biogeography of Recent South America land mammals. In: Mares MA and Genoways HH (Eds), Mammalian biology in South America: Pymatuning Symposia in Ecology 6, Pittsburgh, p. 39-52.

Wilson DE AND ReEDER DM. 2005. Mammal Species of the World: A Taxonomic and Geographic Reference: Baltimore, Johns Hopinks University Press, 2142 p. 